\title{
正燐酸カルシウム・錫けい光体と “真天然色型”*けい光放電管について
}

\author{
正会員 中島 茂春** 正会員 本田芳人** \\ Calcium Orthophosphate: Tin Phosphor and the Super \\ De Luxe Fluorescent Lamps.
}

By Shigeharu Nakajima (Member) and Yoshito Honda (Member)

(Lamp Engineering Dept., Tokyo Shibaura Electric Co.)

\begin{abstract}
Some results of the study on Ca-Sr-orthophosphate phosphor are described. By the development of this phosphor, it was made possible to make a new type of fluorescent lamps which give very good color rendition. As the main constituents of the fluorescent coatings, these lamp; utilize the following combination of phosphors; Ca-Sr-orthophosphate: Sn which makes $3,500^{\circ} \mathrm{K}$ lamps when applied singly to fluorescent lamps, Ba-pyrophosphate: Ti with blue white emission, and $\mathbf{M g}$-Boro-arsenate : $\mathbf{M n}$ which adds the deep red emission. In addition to those three phosphors, Zn-silicate: Mn and Catungstate was used in cool white and daylight type lamps respectively for color adjustment. The available color domain of the lamps with $\mathrm{Ca}$-Sr-orthophosphate: Sn phosphor of various compositions has been studied and plotted on the C.I. E. chromaticity diagram. Also the spectral energy distribution curves, color rendering properties, luminous efficiencies and the lumen maintenance of these new type lamps are dessribed.
\end{abstract}

\section{1. 緒言}

現在，一般照明用けい光放電管には Calcium Halophosphate：Sb Mn 计い光体を主体としたスタンダード

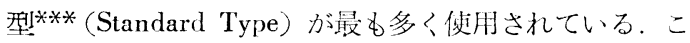
のけい光体はきわめて効率悢好であるが，赤色部の発 光エネルギーが少いために，色特性が覀い欠点をもって いる，そこで効率を多少儀牲にして演色性を改善したの が, 天然色型(De Luxe Type) けい光放電管である。こ の型には大別して二つの系統がある。

一つは約 6,100 凡 に極大を持った亦色忛い光体 Calcium Silicate: $\mathrm{Pb}, \mathrm{Mn}$ を主体としたものであり，他の

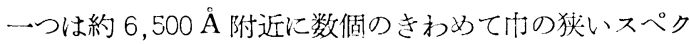
トルを持った深赤色汁い光体 Magnesium Arsenate: Mn を前記 Calcium Halophosphate: Sb, Mn けい光体に附 加したものである。しかしながら耐者共，深赤色部全般 にわたってのェネルギーがやや不足しているために，演 色性のみを雷視する場合の光源としては，な拈不充分の 憾みがあった。

したがって，さらに演色性の良いものを得るために は，深赤色部に充分なェネルギーを有し，しか子可視部 波長域全般にわたってのスペクトル分布曲線が比較的な だらかとなるようにけけい光体を選択組合せる必要があ

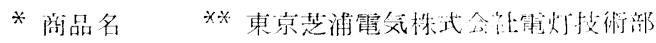

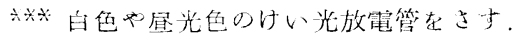

る.この目的のために，二三の梁赤色けい光体を使用 して実験を試みたが。いずれも効率が悪いか或いは安定 度が覀いために実㭌性に乏しかった。

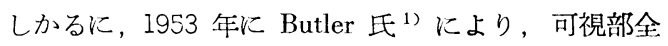
域にわたり巾の広いスペクトルをもち，しかも深赤色部 にも充分なェネルギー学有する一連の Alkaline Earth Orthophosphate けい光体が発表せられた，筆者等はこ れら一連のけい光体の内, Calcium Strontium Orthophosphate : Sn けい光体の実用的価值を試作夹騩火よっ て確認し, このけい光体を単独か, 或いは主成分として 使用することにより，きわめて優秀な演色性を示す“真 天然色型”(Super De Luxe Type) けい光灯を完成した. このけい光体の試作経過ならびに “真天然色型” けい光 灯について紹介する。

な扮本稿で取扱ったスペクトル分布はすべて，マッダ 研究所の自記分光輻射計により測定したものである.

2. Calcium Strontium Orthophosphate $: S n け$ い光体

\section{1 焼成条件}

本けい光体は活性刘である Sn が2 価の形で結晶中に 導入されていることが条件であり，4価の形で存在する 場合は発光しない性質を持っている，文献によれば4 価

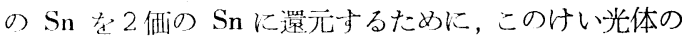
䗊成中拉よび冷却時に $1.8 \% \mathrm{H}_{2}$ のフォーミングガス 
を作用させることにより成功したようであるが，版と $\mathrm{N}_{2}$ との混合比を種々汇変化させたフォーミングガスを 用いて筆者が実験したところによれば， $5 \% \mathrm{H}_{2}$ 以下の フォーミングガスは還元力が不充分であり，㜔成後の冷 却時に 10 25\% $\mathrm{H}_{2}$ のフォーミングガス気卷に曝した 方がよいようである。

本けい光体は基体組成が注ぼ orthophosphate の埸合

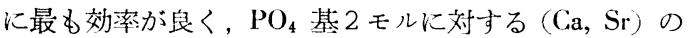
モルが 3.00 を越えると輝きは急速に低下寸る。（Ca, Sr)のモルが 2.88 より小さくなるにつれて, 寸なわち orthophosphate より pyrophosphate に近づくにつれて, 輝きは此較的ゆるやかに低下してゆく（ $\mathrm{Ca}, \mathrm{Sr})$ と $\mathrm{PO}_{4}$ 基の割合が $2.88: 2.00$ の組成の時, 最良の輝きのもの を得られることが予備実験によっても確められた．

したがって，以下の実験結果を示寺試料はすべて $(\mathrm{Ca}$, $\mathrm{Sr})$ と $\mathrm{PO}_{4}$ 基とのモ几割合が $2.88: 2.00$ 亿なる上う 任原料を調合し，1 試料約 100 瓦の単位で取扱った。特 別の場合を除き $1,180^{\circ} \mathrm{C}$ で 75 分電気外で䟞成したの ち, 冷却時に $25 \% \mathrm{H}_{2}$ のフォーミングガスに暴して各 試料けい光体をつくった。

\section{2 組成とスペクトル分布との関係}

本忛い光体の基礎的組成となるものは，Ca-orthophos phate: Sn である.このけい光体は通常 $1,200^{\circ} \mathrm{C}$ 以上の 高温で烧成すると $4,940 \AA$ に極大をもった $\alpha$ 型となり， それ以下の比較的低い温度で焙成されたものは，一般に 約 6,200 凡 に極大を有する $\beta$ 型のスペクトル分布を示 す。これらのスペクトル分布は焼成温度によって変化す るのみならず，烧成時胆，組成とも重大な関係を有する ものである.

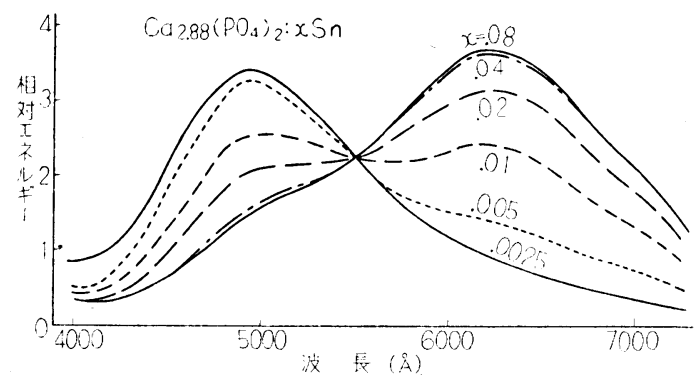

第1図 Snの濃度の変化によるCa-orthophosphate のスペクトル分布曲線

第1 図に活性剤 Snの濃度を変化させた時汇変化する Ca-orthophosphate のスペクトル分布を示寸．Snの濃度 が 0.04 モル以上の場合， $1,180^{\circ} \mathrm{C}$ で㪇成されたものは $6,200 \AA$ に極大をもち，また，4,950 ̊附近にもわずかな

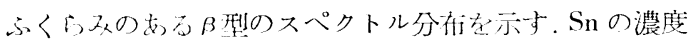

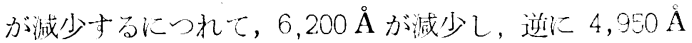

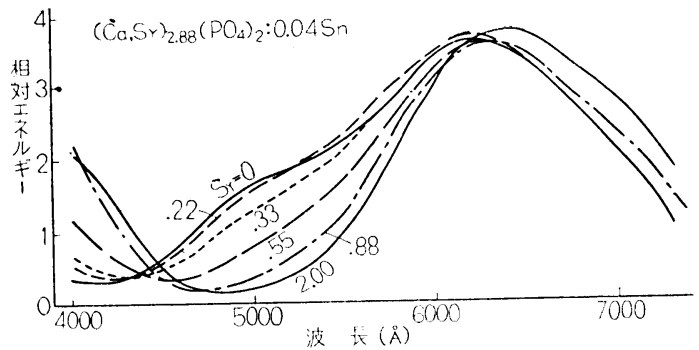

第2図 $\beta$-Ca-orthophosphate $(0.04 モ ル \mathrm{Sn})$ K扔いて $\mathrm{Sr}$ の䈯换に上り变化するスヘクトル分布曲線

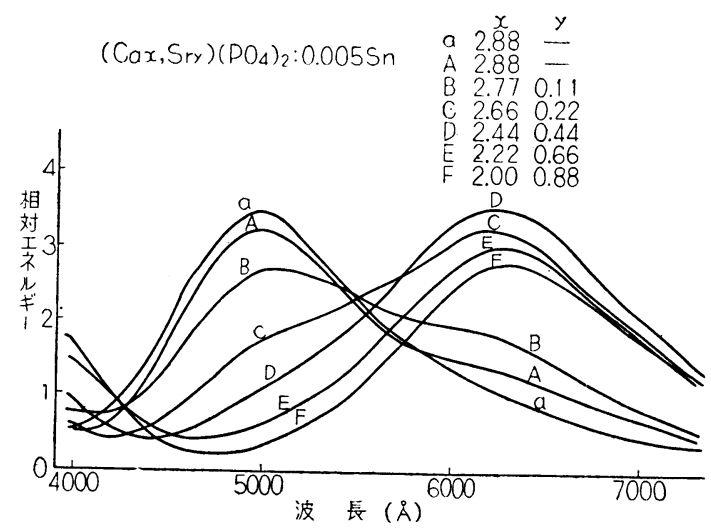

第3図 $\alpha$-Ca-orthophosphate $(0.005 モ ル \mathrm{Sn})$ K括いて Sr の置換により変化するスペクトル分布曲線 が增大与る。 0.005 Sn 以下では 4,950 А に極大を有す る $\alpha$ 型となる。

Sn の濃度がそれぞれ 0.04 モル，0.005 モルの Caorthophosphate に执いて，Ca の一部を $\mathrm{Sr} て ゙$ 置換する ことによって変化するスペクトル分布を第2 図扎よび第 3 図に示す. Sn の濃度が 0.04 モルの場合は Sr の量が

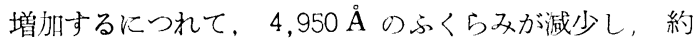

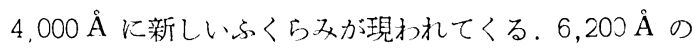
極大の強度はほとんど変化しないが，位圆が長波長側一 移行する. 2.00 モル Sr ではその極大位置は $6,4 \mathrm{CO} \AA$ と なる. Sn の濃度が 0.005 モルの場合は, Sr の量が増

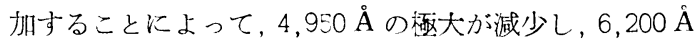
抢よび4,000 Aが增大する。 0.22モル Sr以上では 6,200 A 側が極大となり，0.44モル Srよりさらに增加するに

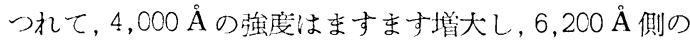
極大は長波長側へずれるとともに，その強度は次參に弱

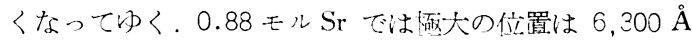
である。

\section{3 発光色範囲}

$\mathrm{Sr}$ の量抢よび Sn の濃度を変化させてつくった各けい 光体をバルブに浦布しで，それぞれ $20 \mathrm{~W}$ けい光放電管

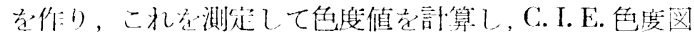
上に示したのが第4図である。 


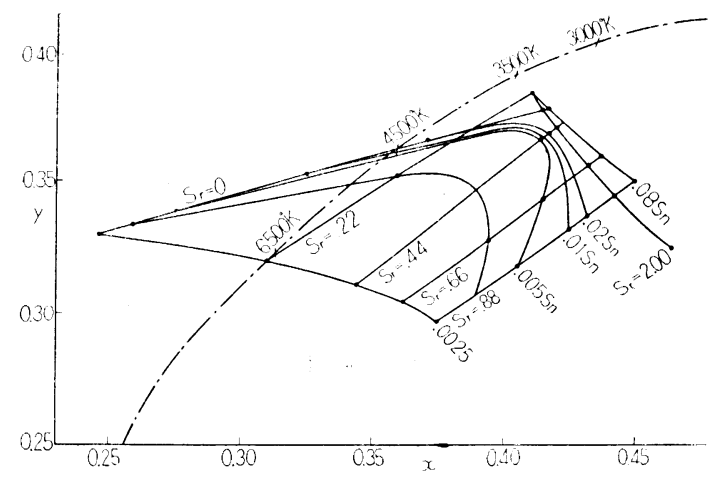

第 4 図 $20 W$ けい光灯とした Ca-Sr orthophosphate: Sn けい光体のCIE 色度図上に扣ける発色範囲

Sr 量の等しい点を結ぶと直線となり，Sr 量が 0.22 モ ル以上では $3,500^{\circ} \mathrm{K}$ より $6,500^{\circ} \mathrm{K}$ の黑体輻射軌跡と ほぼ並行している。また Snの濃度が等しい点を結ぶ線 は大略黑体輻射軌跡と直角になっているが，中央部では 弓形の曲線となっている。これは Sr の量和よび Sn の 濃度の差異によってつくられたけい光体の輝きが異なる ため，けい光放電管にした場命水銀可視線による影響の 強弱があらわれたものである。

Snの濃度が 0.04 モルの場合は Ca を Sr で置換して行 くと, Sr 0.22 モルまでは $3,500^{\circ} \mathrm{K}$ 附近の黑体軌跡に近 づき,これをこえると逆もよ゙りして0.33モルでは大体も との位置にもどり，それ以上はますます離れて再び近づ くことはない。したがってこのけい光体の組成を選択す ることにより，単独でそれぞれ $3,500^{\circ} \mathrm{K}, 4,500^{\circ} \mathrm{K}$ 就よ び 6,500 ${ }^{\circ} \mathrm{K}$ の色温度走示与忛い光放電管を作ることが できる。

\section{4 輝き}

Sr 量がそれぞれ罣るものについて，Snの濃度と輝き

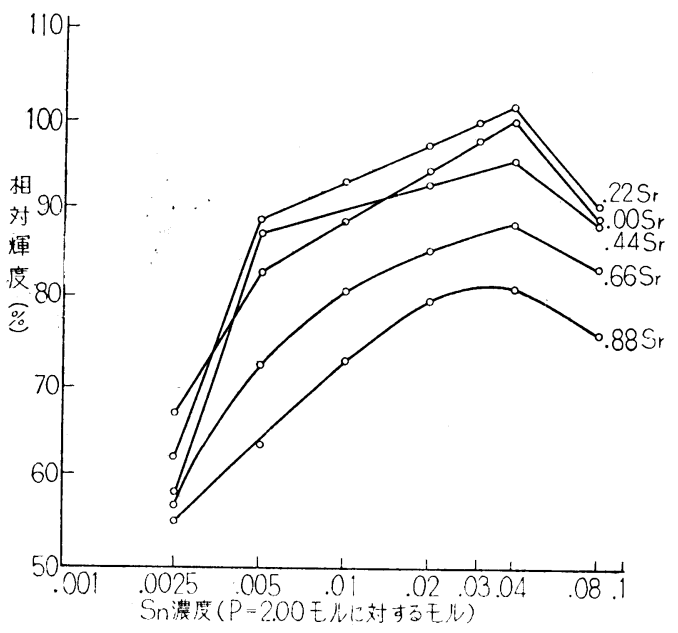

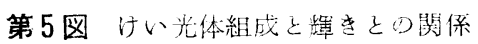

との関係を第 5 図に示す.Snの濃度を対数日盛にとると 0.005〜0.04 モルの濃度範井では，ほぼ直線関係を示す。 0.22 モル Sr が最も高い輝きを有し, Sr 量がそれ以上增 加するにしたがって，輝きはだんだん低下して行く．Sn の濃度は 0.04 モルの時最も輝さが高く, それより減小 しても堌加しても輝きは低下寸る. Sn の濃度が 0.005 モ

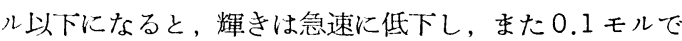
は活とんど光らない，最高の輝きを示すものの組成は $\left(\mathrm{Ca}_{2 \cdot 66} \mathrm{Sr}_{0 \cdot 22}\right)\left(\mathrm{PO}_{4}\right)_{2}: 0.04 \mathrm{Sn}$ である.

\section{5 考 察}

Butler 氏1) はこのけい光体について, Sr 量が増加する 之, $6.300 \AA$ の極大が $6,150 \AA$ の方向へ, すなわち, 短 波長側へずれると発表しているが，筆者等の上記実験結 果は明らかに長波長側へずれることを示した。

このけい光体のスペクトル分布は組成と重大な関係を もっているのみならず，焼成温度および烛成時間とも密 接な関係を有している.たとえば，第3図に示した曲線 $a$ は $1,200^{\circ} \mathrm{C}$ で, また曲線 $\mathrm{A}$ は $1,180^{\circ} \mathrm{C}$ で绻成してで きた $\mathrm{Ca}_{2.88}\left(\mathrm{PO}_{4}\right)_{2}: 0.005 \mathrm{Sn}$ 外い光体スペクトル分布で

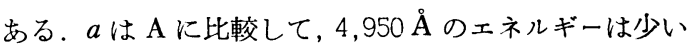
が, そのかわりに $6,200 \AA ̊$ 附近のエネルギーを余分にも っている。このことは, 㜔成温度が $20^{\circ} \mathrm{C}$ 高いために, A に存在している $\beta$ 型が, そのエネルギーの差たけ $\alpha$ 型 に転換されたことを示すと考えられる. Sr を含む場合も 特に Sn の濃度が低い場合にこの傾向が大きい. $10^{\circ} \mathrm{C} の$ 烧成温度差は明らかにけい光体の発光色を变化させる. また㜔成時間の長短も，まったく焼成温度の高低と同じ 効果をあたえることが，芙験中しばしば経験された。

このけい光体の組成を適当に選択すればけい光放電管 を製作した場合，単独でそれぞれ $3,500^{\circ} \mathrm{K}, 4,500^{\circ} \mathrm{K}$ お よび $6,500^{\circ} \mathrm{K}$ の色温度を示すけい光体を作ることが可能 である、すなわち, $\left(\mathrm{Ca}_{2.66} \mathrm{Sr}_{0.22}\right)\left(\mathrm{PO}_{4}\right)_{2}: 0.03 \sim 0.04 \mathrm{Sn}$ の組成を持ったものは,最も $3,500^{\circ} \mathrm{K}$ 黒体軌跡に近い色 温度をしめし, 效率よくしかも比較的安定したものが作 られる長所を持っている。これに反して単独で $4,500^{\circ} \mathrm{K}$ および $6,500^{\circ} \mathrm{K}$ の色温度を示す組成のものは, $\mathrm{S}$ の濃 度が低いために，上記の如き影響を受け易く，また，効 率も劣るので事用性に之しい。

\section{3. “真天然色型”けい光放電管}

\section{1 けい光体組合せ}

上記の奏験研究によって完成した Ca-Sr-Ortho-phosphate : Sn けい光体を使用して, 各色温度の真天然色型 けい光放電管を作った。すなわち，3,500K にはこのけ

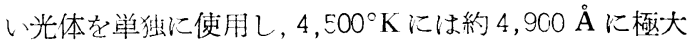
克持った青当色に発光する Barium Pyrophosphate: Ti 
けい光体 ${ }^{2}$ を組命せ，さらに深赤色部工ネルギーを補充 するために, 約 6,500 A 附近に極めて币の狭いスペクト ルをもった Magnesium Boro-Arsenate:Mn けい光体を 添加し, なお, 色度調整のために少量の緑色けい光体

\section{(1) Calcium Tungstate}

(2) Barium Pyrophosphate: $\mathrm{Ti}$

(3) Zinc Silicate $\mathrm{Mn}$

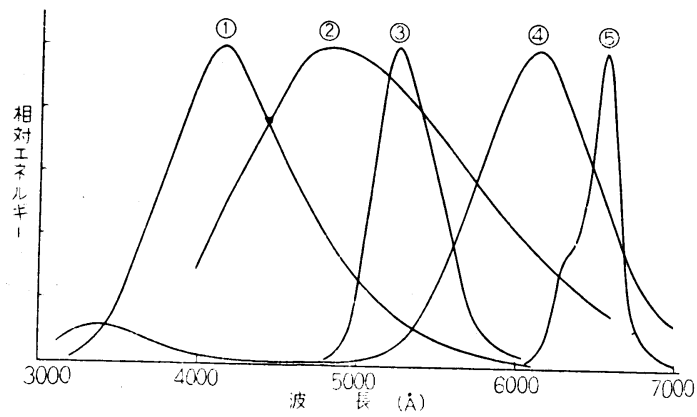

第 6 図各種けい光体のスヘクトル分布

Zinc Silicate: Mn を配合した.6,500K にはこのけい 光体に Barium Pyrophosphate: Ti けい光体, Magnesium Boro-Arsenate: Mn けい光体扐よび色度調整のため, 約 4,150 A に極大をもち, 深青色に発光する Calcium Tungstate けい光体を配合した。第6図は使用したこれらの けい光体のスペクトル分布を示寸.

\section{2 スペクトル分布}

第 7,8,9图にそれぞれ，各色温度のマッダ真天然色怗 い光放電管のスペクトル分布曲線を示す.なお,参考のた めにそれぞれの色温度に打ける規準光源のスペクトル分 布,および $3,500{ }^{\circ} \mathbf{K}$ にはマツダスタンダード型 $3,500^{\circ} \mathrm{K}$ けい光放電管， $4,500^{\circ} \mathrm{K}, 6,500^{\circ} \mathrm{K}$ にはそれぞれ往来 のマッダ天然色型けし 光放電管, および, マッダスタン ダード型けい光放電管のスペクトル分布を併記した。

真天然色型けい光放電管は天然色型けい光放電管に比 ベて, 深赤色部ェネルギーが，さらに增加して拈り，し かもその分布曲線は可視部波長域全般にわたって，なだ らかとなっていて, 規準光源のスペクトル分布に最も似 たスペクトル分布を示している。

\section{3 演色性}

真天然白色けい光放電管（FI-W-SDL）抬よび，真天然 㡺光色けい光放䉓管 (FL-D-SDL) の演色性走, 東一森式

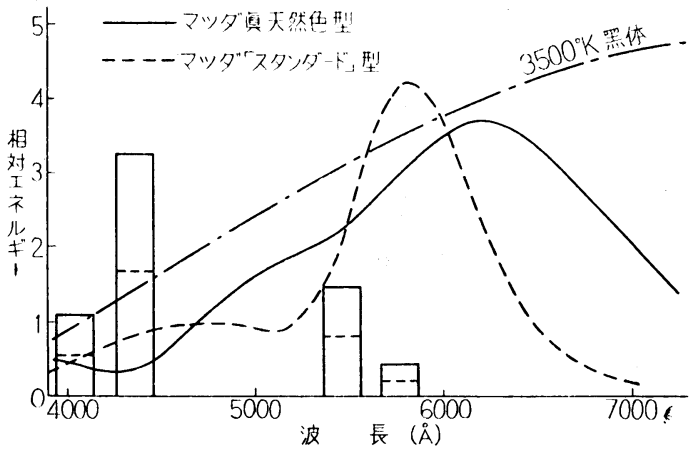

第7図 $3,500^{\circ} \mathrm{K}$ 各種けい光灯のスベクトル分布図

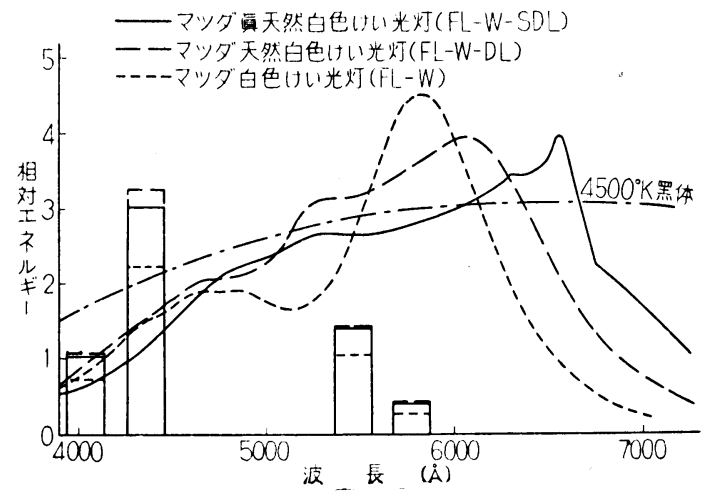

第8図 4,500 $\mathrm{K}$ 各種けい光灯のスペクトル分布図

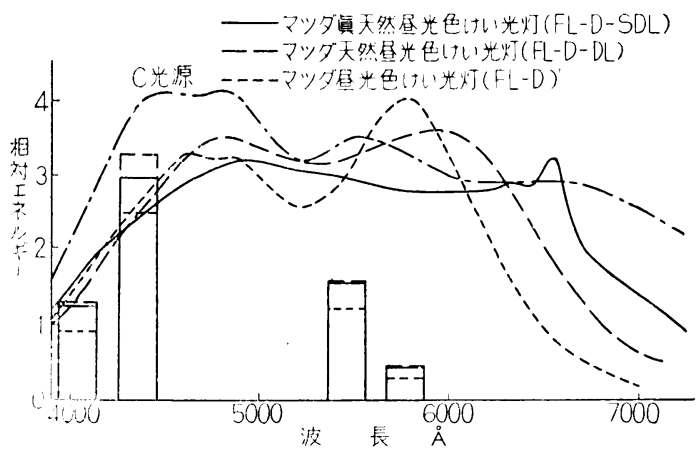

第9図 6,500 $\mathrm{K}$ 各種けい光灯のスペクトル分布図 演色性評洒洗 ${ }^{3)}$ によって計算した結果を，彷来の各種け い光放電管と比較して第 1 表に示した。また，この場合 の明度のずれを第 10 図, 第11 図に示したが, 真天然色
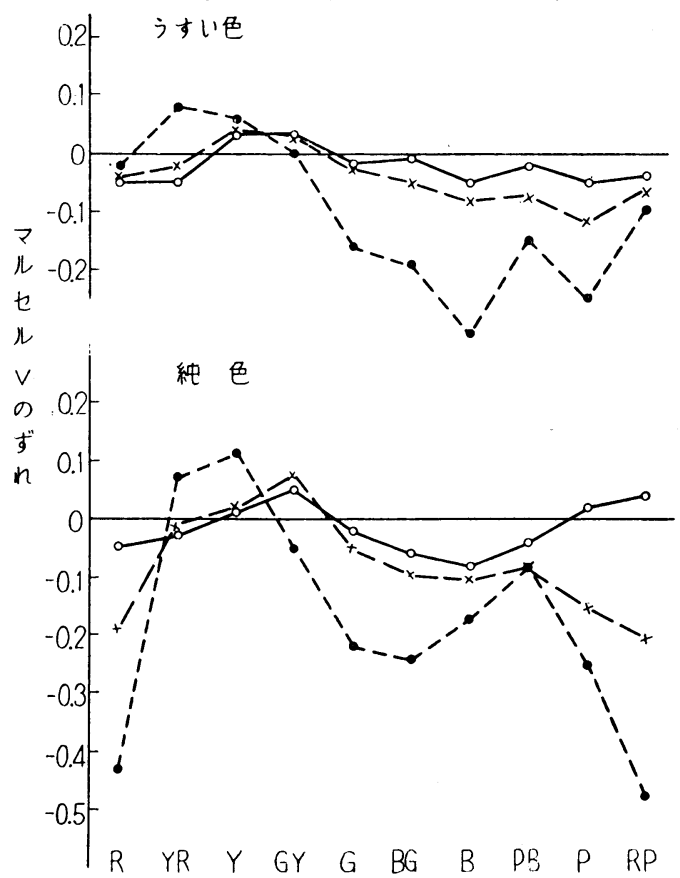

第 10 図4,5C0 K けい光灯による色紙の明度ずれ 

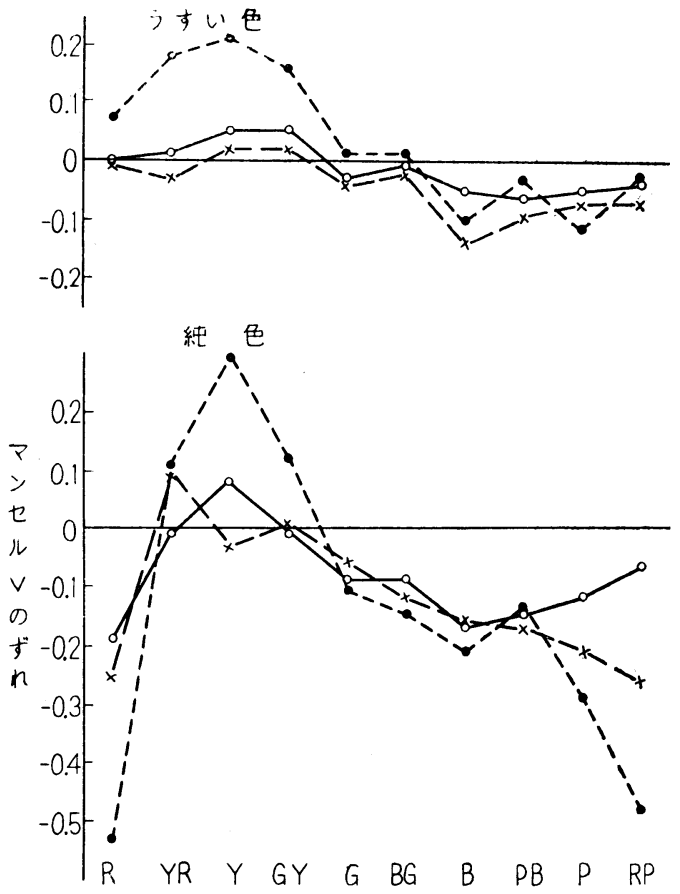

篹11図 $6,500^{\circ} \mathrm{K}$ けい光灯による色紙の明度ずれ

第 1 表 マッダけい光灯の演色性評価点

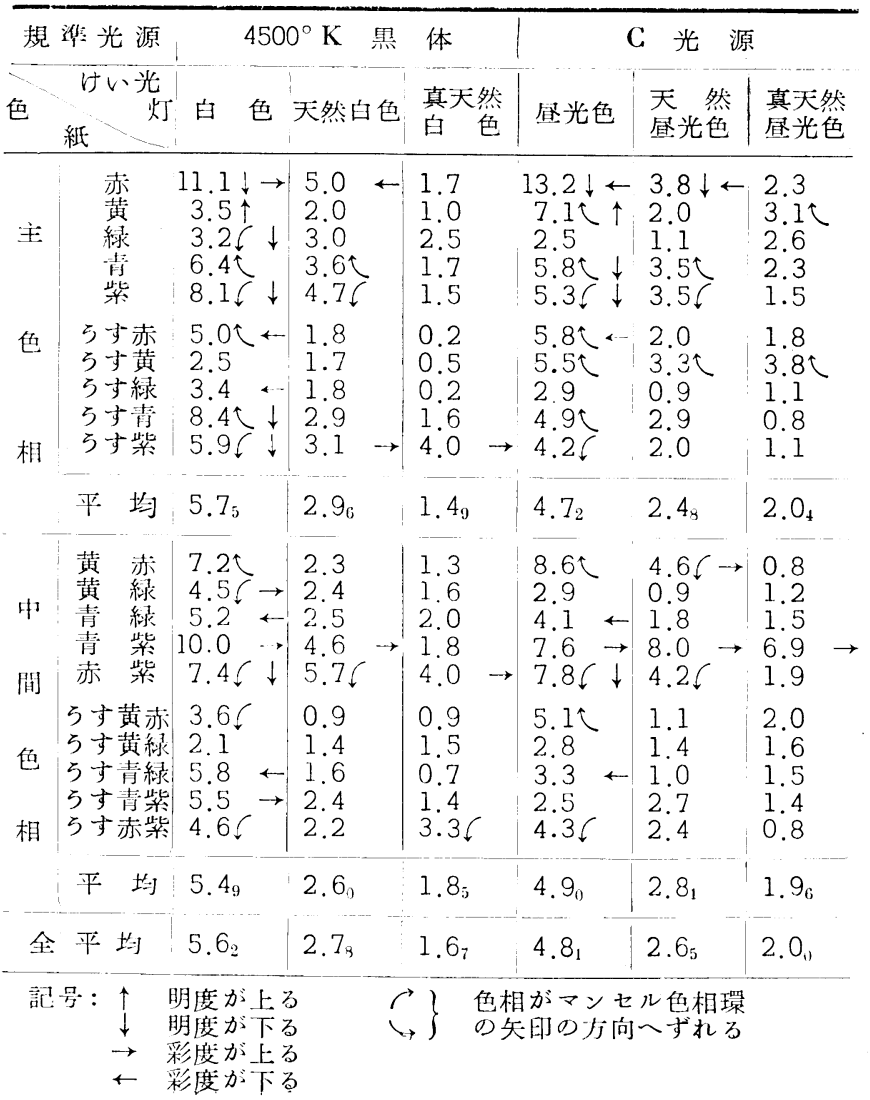

型けい光放電管は明度のずれは最も少い。

評価点は規隼光源と比較した場合の「色ずれ量」を表 わす。したがって点数の小さいほど，その色に対する演 色がよいということになる．点数が

3 以下の場合は 色差はほとんど見分けられない

3〜6の場合は 注意して見れば色差が見分けられる

6 以上の場合は はっきりと色差が見分けられる と考えてさしつかえない.

演色性評価点の示す如く真天然色型けい光放電管は, 従来の天然色型の演色性をさらに改善したもので，ほと んど総での色に対し極めて優秀な演色性を示している。

\section{4 效率および光束減衰}

真天然色型けい光放電管は演色性に重点を置いて作ら れたものであるため, 従来の天然色型けい光放電管より 効率は約 $10 \%$ 少っている. 第 2 表に 40 W 管についての効率 $(\mathrm{lm} / \mathrm{W})$ を示寸.

第 2 表 マッダ 40 W 普通型けい光灯の効率 $(\mathrm{Im} / \mathrm{W})$

色 $\left(6,500^{\circ}\right.$ 急) $\left(4,500^{\circ} \mathrm{K}\right) \quad 3,300^{\circ} \mathrm{K}$

\begin{tabular}{cll|l} 
真天然色型(SDL) & 46 & 46 & 43 \\
天然色型(DL) & 51 & 51 & 70 \\
スタンダード型 & 58 & 67 & 70
\end{tabular}

効率と演色性は相反する関係にあり，演色性が向上す るにしたがって效率が低下するのはやむをえないるので ある、しかしながら，この真天然色型けい光放電管は優 秀な演色性を示す割には色好な効率を示して いる.

つぎに，光束減衰は往来の各種天然色けい 光放電管に比較して優るとも劣らないもので あり，また，点灯時間によって生ずる色ずれ

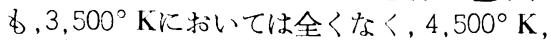
$6,500^{\circ} \mathrm{K}$ において子肉眼で判別し得る程度に は存在しない。

\section{4. 結 言}

以上, Ca-Sr-orthophosphate: Sn けい光体 およびこれを使用した真天然色型けい光放電 管について紹介した。このけい光放電管が完 成されたことによって, 徉来の天然色型けい 光放電管でも, な扰，不充分であるとされて いたような，高度の演色性を必要とする場 所, 例えば, 美術館, アトリエ, 高級只服店。 印刷・染色工場等の色彩鑑賞・鑑別倣光源と してその効果を期待し得るものである。

擱筆するに当り，測色に関して絶大なる御 援助を戴いたマッダ研究所東博士および特に Mg-Bora-Arsenateけい光体について御指導を 晹った同研究所上原博士に対して厚く感謝致 します:

(昭 $31-1-11$ 受付)

\section{文献}

1) K. II. Butler: J. Electrochem. Soc., 100 (1953) 250.

2) S. T. Henderson and P. W. Ranby: J. Electro-chem. Soc., 98 (1951) 179.

3）東 墔・森礼於: 照学誌 38 (昭 29) 187. 